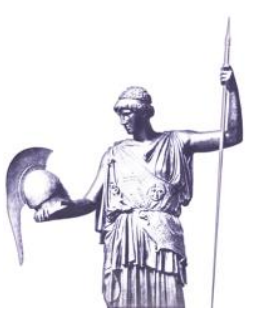

Research Article
Connections: The Quarterly Journal

ISSN 1812-1098, e-ISSN 1812-2973

Sebastian von Münchow and Lena Hantschke, Connections QJ 16, no. 2 (2017): 25-39 https://doi.org/10.11610/Connections.16.2.02

\title{
Parliamentary Attempts to Investigate Berlin's Vehicular Ramming Attack
}

\section{Sebastian von Münchow and Lena Hantschke}

George C. Marshall European Center for Security Studies, http://www.marshallcenter.org

\begin{abstract}
On December $19^{\text {th }}, 2016$ Germany saw the first major Islamist terror attack on its soil. A Tunisian asylum seeker crashed a hijacked truck into one of the main Berlin's Christmas markets. The assault resulted in 12 casualties. In the aftermath, several attempts were made by German parliaments on Länder-level, as well as on federal level, to investigate how the terrorist was able to use 14 different identities, how he carried out the plot, how he escaped and where security authorities failed to prevent the attack.
\end{abstract}

Keywords: Law enforcement, Germany migration, parliamentary oversight, terrorism, counterterrorism, intelligence cooperation.

\section{Introduction}

On the evening of December $19^{\text {th }}, 2016$, Anis Amri, a Tunisian asylum-seeker, hijacked a truck, killed the driver, and crashed into a Christmas market in Berlin. The Islamic State claimed responsibility for the attack, which resulted in twelve deaths and fifty additional casualties. ${ }^{1}$ Amri escaped the crime scene and travelled by train through Germany, the Netherlands, Belgium, and France to Northern Italy. In the morning of December $23^{\text {rd }}$, Italian police officers shot him dead in the town of Sesto San Giovanni, near Milan.

1 "OSINT Summary: Vehicle impact attack on Berlin Christmas market highlights increasing adoption of tactic," IHS Jane's Terrorism \& Insurgency Monitor, December 20, 2016, http://janes.ihs.com/TerrorismInsurgencyCentre/Display/1791686. 
This assault was the first major Islamist terrorist event on German soil that resulted in the deaths of civilians. ${ }^{2}$ The attack re-heated the debate about Berlin's migration policy at large, but also focused on specific questions: How could Amri seek asylum in Germany despite his criminal record in Italy? How did he operate inside Germany using 14 different identities? How could Amri travel through five European countries before he was shot dead? ${ }^{3}$ Throughout the state and federal levels, calls for security-related reforms, ${ }^{4}$ aimed at improving video surveillance, data exchange, increasing the staff of security agencies and tougher deportation procedures, flourished. In parallel, the question unfolded which legislative institutions could do a thorough ex post investigation of the plot? $^{5}$

This contribution uses the Anis Amri case to illustrate the complexity of the German federative system, the diversity of law enforcement jurisdictions and respective parliamentary inquiries. It will not focus on the police aftermath reports, but instead will look at those investigations by ad hoc parliamentary committees which examine allegations of executive misconduct or failure. This

2 There was one attack in March 2011 in Frankfurt. It is considered to have an Islamist background. Arid Uka, a presumed self-radicalized youngster of Kosovar origin, killed two U.S. airmen and wounded two others when they wanted to board a plane at Frankfurt Airport. For further information on the incident see "Frankfurt Airport shooting: two US-serviceman dead," $B B C$ News online, March 2, 2011, www.bbc.com/news/world-europe-12621832, and "Frankfurt airport gunman jailed for life," BBC News online, February 10, 2012, www.bbc.com/news/world-europe16984066.

"Berlin truck attack: Can the EU stop another Amri?" BBC News, January 6, 2017, http://www.bbc.com/news/world-europe-38517768. See also "The Berlin Vehicular Ramming Attack - What we know \& Insights from ICT Experts," The International Institute for Counter-Terrorism (ICT) online, December 22, 2016, www.ict.org.il/ Article/1883/the-berlin-vehicular-ramming-attack.

4 “Gegen Terrorismus hilft nur Besonnenheit," Der Tagesspiegel online, February 2, 2017, www.tagesspiegel.de/politik/gesetzentwurf-zu-fussfesseln-gegen-terrorismushilft-nur-besonnenheit/19335506.html. Note the intention to introduce an early warning mechanism called RADAR: "Neues System zur besseren Gefährder-Einschätzung," Berliner Zeitung online, January 21, 2017, http://www.berlinerzeitung.de/politik/neues-system-zur-besseren-gefaehrder-einschaetzung-25588238. NRW law enforcement reform plans: "Was die Polizei in NRW verbessern will," Spiegel online, February 13, 2017, http://www.spiegel.de/politik/deutschland/anisamri-was-die-polizei-in-nrw-nach-anschlag-in-berlin-verbessern-will-a-1134309.html.

5 "Sicherheitsdebatte: Souverän gegen Terror," FAZ online, January 11, 2017, www.faz.net/aktuell/politik/inland/sicherheitsdebatte-souveraen-gegen-terror14613401.html. See also Federal Minister for Internal Affairs, Thomas de Maizière's statement "Sicherheit als gemeinsame Verantwortung," Bundesregierung, January 28, 2017, https://www.bundesregierung.de/Content/DE/Interview/2017/01/201701-28-de-maiziere-spiegel.html. 
brief discourse will help to understand the distinct jurisdictions of the states ("die Länder") and the federal level. Therefore, the paper elaborates on the parliamentary investigations from the City of Berlin as one of the 16 German states, then turns to the state of North-Rhine Westphalia (NRW) and subsequently introduces federal attempts where ex post investigations took place. Finally, the contribution will share some thoughts about the eventual achievements by the parliamentary endeavors to shed light on the attack.

\section{Germany's Federative Security Structure}

Maintaining public order and security in Germany falls under the jurisdiction of the 16 federal states. In consequence, Germany counts 16 departments of home affairs, 16 law enforcement agencies, 16 domestic intelligence services, 16 respective judicial bodies, and 16 different laws of public order. In the case of incidents that affect two or more states or have a transnational dimension the Federal Criminal Police Office (Bundeskriminalamt - BKA), working under the auspices of the Ministry of Internal Affairs (Mol), can take charge if the legal requirements are satisfied. ${ }^{6}$ In 2004, the Joint Counter Terrorism Center (Gemeinsames Terrorismusabwehrzentrum, GTAZ) was founded as a fusion center where intelligence and law enforcement agencies of the federal and state level share their information. However, the GTAZ does not stand as a distinct authority itself. This is due to the "Trennungsgebot" which prevents intelligence authorities' use of law enforcement instruments, such as placing someone under arrest.

\section{State and Federal Inquiries}

In terms of standing committees, an ex post investigation can be achieved via the internal affairs units on the federal and state levels. Additionally, the Parliamentary Control Panel (Parlamentarisches Kontrollgremium, PKGr) can conduct investigations on the federal level regarding topics related to the intelligence services. A special investigator can be appointed on the federal as well as on Länder-level. ${ }^{7}$ Such an investigator has the right to review files and talk to involved individuals.

6 The legal requirements are defined in the statute of the German Federal Police (Bundeskriminalamtsgesetz, BKAG, § 4).

7 The legal basis for the appointment of a special investigator is article 10 of the Law of the Committees of Inquiry (Paragraph 10 Parlamentarisches Untersuchungsausschussgesetz, PUAG) on federal level. It corresponds with similar legislation on state level. The government (be it state or federal level) can appoint a special investigator via its governmental authority. The appointment of a special investigator by the executive branch cannot prevent the legislative branch from fully exercising its investigative rights, e.g. implementing an ad hoc inquiry committee. 
Finally, a retroactive review of a case can also be conducted through the establishment of an ad hoc parliamentary committee of inquiry on the state or federal levels. This option provides the most powerful tools to reveal shortcomings and loopholes in the legal framework. The right to look into documents is far reaching, and questioning staff members from all hierarchical levels usually takes place in an open forum involving the press. $^{8}$

For the time being, several different inquiry committees have started their work on the Amri case on the state level. Nevertheless, an inquiry committee of the German Bundestag, dominated by the Grand Coalition between Conservatives and Social Democrats, has so far not been implemented.

\section{Berlin}

Like other crimes, terrorist attacks initially fall under the jurisdiction of the affected federal state. Berlin, like Hamburg and Bremen are cities, but enjoy each the status of a state in the federation of the total 16 states forming the Republic. Thus, Berlin's Social Democratic Senator of Home Affairs and the State Police (the Landeskriminalamt, LKA) are the institutions in charge of investigating a plot executed in their city. Allegations against the LKA in regards to misjudging Amri as a danger caused the Berlin Landeskriminalamt and the Public Prosecutor's Office Berlin to form the Taskforce "Lupe" (German for 'magnifying glass'). The taskforce's mandate was to examine whether the LKA case-workers and their supervisors played a role in the development leading to the fatal attack. Hence, this internal inquiry serves also to revisit control mechanisms within the structure of the LKA and may lead to additional disciplinary action against staff members.

\section{Berlin's Assembly and Internal Affairs Committee}

The attack became the subject of debates in Berlin's Assembly (Abgeordnetenhaus) and the Committee on internal affairs. ${ }^{9}$ The incident is still on the agenda and has so far been discussed in several meetings over the last few months,

8 The chairman of the Christian Democratic Union fraction Mr. Volker Kauder declared to be in favor of an ad hoc inquiry committee by the German Bundestag. He would suggest this to his Social Democrat counterpart, Mr. Thomas Oppermann. See Martin Lutz and Constanze Reuscher, "Anis Amri soll regelmäßig Drogen genommen haben," Welt online, January 15, 2017, www.welt.de/politik/deutschland/article161179412/ Anis-Amri-nahm-regelmaessig-Ecstasy-und-Kokain.html.

“Berliner Anschlag: Verhallte Warnungen aus Marokko," Telepolis, January 31, 2017, www.heise.de/tp/news/Berliner-Anschlag-Verhallte-Warnungen-aus-Marokko-

3611242.html. See also "Terroranschlag erneut einziges Thema im Innenausschuss," Berliner Morgenpost online, January 22, 2017, www.morgenpost.de/berlin/article 209356113/Terroranschlag-erneut-einziges-Thema-im-Innenausschuss.html. 
most recently on July $3^{\text {rd }}, 2017 .^{10}$ During this session, a Special Investigator (see the next section) and a Head of the Counterterrorism Department of the Federal Public Prosecutor General presented their investigation's findings.

At the beginning of this hearing before Berlin's Committee on internal affairs, the Department Head of the Federal Public Prosecutor stressed that his appearance before the Committee had an exceptional character. He argued that he is only obliged to appear before a competent forum of the German Bundestag. Indeed, his cooperation is based on good will. The Department Head represents a federal authority and cannot be forced by the committee on Länder-level to appear as a witness. In consequence, the Berlin members of the committee could not directly address him with questions during the meeting. The questions had to be submitted in advance. The Department Head of the Federal Public Prosecutor summarized the current state of the ongoing investigation and thereafter only answered selected questions. He also mentioned several transnational elements of the attack. First, Anis Amri was in continuous contact with at least one foreign IS-member via text messages while conducting the attack. Second, there are hints of further possible confidants or accomplices in other nations. Third, the weapon he used can be traced back to Switzerland. In this light there have already been investigations in other states. Eurojust, a European network of public prosecutors, was involved. Mutual legal assistance requests were sent to Belgium, the Netherlands, Great Britain, Italy, Austria, Poland, Switzerland, Spain, France, Tunisia and the U.S.A.

\section{Special Investigator}

Berlin's Social Democrat, Socialist and Green Party-led city government, the "Senat," appointed Mr. Bruno Jost as a Special Investigator. As a retired prosecutor, he was thought to be the best to handle this task and submit findings to the committee. He started work in April 2017. A final report is expected in October $2017 .^{11} \mathrm{Mr}$. Jost presented an interim report to the aforementioned committee session on July 3rd, 2017.

During the investigation, the focus shifted from examining the general preconditions that allowed the attack to happen to the review of report by the LKA Berlin, which might have been subsequently edited. It was alleged that the editing took place to cover mistakes by the LKA that prevented the detention of

10 See protocol of the meeting, July 3, 2017, www.parlament-berlin.de/C1257B550 02AD428/CurrentBaseLink/W29ASL7D644DEVSDE?Open\&Wahlperiode=18\&Vorgang $=0023 \&$ Ausschuss=Ausschuss für Inneres, Sicherheit und Ordnung.

11 "Ex-Bundesanwalt Jost wird Sonderermittler im Fall Amri," BerlinOnline, April 3, 2017, https://www.berlinonline.de/aktuell/4811000-4015970-exbundesanwalt-jostwird-sonderermittler.html; and "Amri-Sonderermittler klagt über Probleme bei der Akteneinsicht," Der Tagesspiegel online, May 16, 2017, www.tagesspiegel.de/berlin/ polizei-justiz/attentat-am-breitscheidplatz-in-berlin-amri-sonderermittler-klagtueber-probleme-bei-der-akteneinsicht/19801570.html. 
Amri before the attack happened. This particular aspect is indirectly linked to the question of possible surveillance of Amri by the security authorities. However, the report was alleged to have been edited in January 2017 after the vehicular ramming attack. Hence, the LKA Berlin was accused of rewriting the findings to its favor. The interim report stated there was a police note about Amri acting as a drug dealer from November 1st, 2016. This first version concluded that Amri and collaborators were dealing drugs on a large scale. The important observation would have been sufficient to justify further surveillance, or even the issuance of an arrest warrant. According to the procedures, this observation should have been sent to the Public Prosecutor's Office in Berlin for further decisions on actions against Anis Amri. Nevertheless, this did not happen. Instead the second version appeared in January 2017. The findings by the Special Investigator suggest that this paper dated back to November $1^{\text {st }}, 2016$ and has elements different from the first edition. It stated that Amri only dealt drugs on a very low level, and did not mention any accomplices. This portrayal could not have been a justification for further surveillance or even an arrest warrant. Thus, the LKA Berlin was confronted with the accusation that it unintentionally prevented further actions against Amri by not forwarding the first report to Berlin's Public Prosecutor's office. This led to the above-mentioned criminal investigations against the involved police officers due to the suspicion of document fraud. ${ }^{12}$ To this day, this aspect is subject to speculation since the allegation is built upon the assumption that the Public Prosecutor's Office would have led to further surveillance or an arrest of Amri.

In his hearing at the Standing committee of home affairs at the Berliner Abgeordnetenhaus on July $19^{\text {th }} 2017$, the Special Investigator said that he is currently focusing on this aspect. He also promised to take a deeper look into other related questions of eventual misconduct before submitting the final report. $^{13}$

Another interesting part of the findings of the Special Investigator in Berlin is that they differ slightly from the findings of the Special Investigator in North Rhine-Westphalia. In particular, Mr. Jost stated that Amri could have been arrested to secure his return to Tunisia. The Asylum Act states an arrest is lawful in cases where the removal of the foreigner seems possible in due time, ${ }^{14}$ which is only the case when citizenship is being confirmed. For individuals who

12 "Anschlag in Berlin - weitere Manipulationen an Akte Amri," Zeit online, May 21, 2017, http://www.zeit.de/politik/deutschland/2017-05/anschlag-berlin-anis-amriIka-manipulation-akten.

13 See protocol of the meeting of the committee of home affairs Berliner Abgeordnetenhaus, July 19, 2017, https://www.parlament-berlin.de/C1257B55002AD428/ CurrentBaseLink/W29ASL7D644DEVSDE?Open\&Wahlperiode=18\&Vorgang=0085\&A usschuss=Ausschuss für Inneres, Sicherheit und Ordnung.

14 The legal requirements are defined in the German Asylum Act (Aufenthaltsgesetz, AufenthG, § 62 Abs. 3 S. 3). 
enter Germany without a passport, the so-called PEP-procedure (Passersatzpapiere, PEP) intends to verify their nationality and identity. This procedure enables authorities to approach the assumed country of origin to confirm the identity and citizenship. Tunisian authorities responded in October $2016^{15}$ confirming Amri's identity, origin, and citizenship. Consequently, a detention would have been lawful. The NRW Special Investigator concluded that the detention of Amri would not have been in accordance with the Act at any stage of the events (see next section).

\section{Ad hoc Inquiry Committee}

Berlin's Assembly also formed an ad hoc inquiry committee on the incident. It started its work on July $14^{\text {th }}, 2017 .{ }^{16}$ Due to the parliamentarian summer break there are no work results yet.

\section{North Rhine-Westphalia}

Amri registered as an asylum seeker in NRW and was partly surveilled by state security authorities. Unlike Berlin, the NRW deputies established two parliamentary inquiries. A brief, but intense ad hoc investigation took place under the former Social Democrat-Green Coalition from February until May 2017; a second was launched on July $1^{\text {st }}, 2017^{17}$ after a Conservative-Liberal government took office in the beginning of June 2017. Given that the inquiry mandates in two Länder take place under two separate jurisdictions, the parliamentarians need to rely on a voluntary exchange of files between the respective entities in Berlin and NRW's capital Düsseldorf, as well as on the good will of any federal institution.

15 Germany's federal Minister for Home Affairs Thomas de Maizière said that Tunisian authorities confirmed Amri's identity in October 2016: "De Maizière zum Fall Amri Antrag auf Abschiebehaft hätte gute Erfolgsaussichten gehabt," Spiegel Online, January 28, 2017, www.spiegel.de/politik/deutschland/thomas-de-maiziere-anisamri-haette-in-abschiebehaft-genommen-werden-koennen-a-1132010.html. Berlin's Special Investigator stated that Amri's identity was confirmed already in August 2016; see protocol of Berlin's assembly meeting on July 3, 2017, www.parlamentberlin.de/C1257B55002AD428/CurrentBaseLink/W29ASL7D644DEVSDE?Open\&Wahl periode $=18 \&$ Vorgang=0023\&Ausschuss=Ausschuss für Inneres, Sicherheit und Ordnung.

16 See press release of the Berlin Assembly, July 11, 2017, https://www.parlamentberlin.de/C1257B55002AD428/vwContentByKey/W2AP6F5Y454WEBSDE.

17 See press release of NRW's house of deputies, July 1, 2017, www.landtag.nrw.de/ portal/WWW/GB_II/II.1/Pressemitteilungen-Informationen-Aufmacher/Pressemit teilungen-Informationen/Pressemitteilungen/2017/06_neues_Impressum/Unter suchungsausschuss_\%26\%23132Fall_Amri\%26\%23147_eingesetzt.jsp. 


\section{House of Deputies}

As in Berlin's Assembly, the attack was also subject to debates in NRW's House of Deputies, the Landtag, and the respective committee on internal affairs. ${ }^{18}$ The issue was discussed in several ad hoc meetings of the committee. Several representatives of security bodies were invited to answer questions related to the case and Amri's record in NRW. ${ }^{19}$

\section{Special Investigator}

A Special Investigator was also in charge of examining Amri's deadly course of action. NRW's state government assigned a criminal law professor to serve in this position. ${ }^{20}$ The scholar's report found that the authorities in NRW did not make crucial mistakes. On the contrary, he continues, NRW state police warned Berlin authorities about a potential risk of a terrorist attack conducted by Amri. According to this view, the authorities in Berlin ignored the warning.

The professor did not clearly point out under which circumstances NRW warned Berlin about Amri. It was discovered that Amri was discussed in several

18 "NRW-Ausschuss diskutiert Berliner Attentat: Anis Amri nutzte 14 Identitäten," Der Spiegel online, January 5, 2017, www.spiegel.de/politik/deutschland/anschlag-inberlin-ralf-jaeger-aeussert-sich-zu-anis-amri-a-1128697.html. See also "Nach Anschlag in Berlin: Die Gefährlichkeit des Anis Amri," FAZ online, January 5, 2017, http://www.faz.net/aktuell/politik/rechtfertigung-von-innenminister-jaeger-wegenanschlag-14606371.html; and "Tunis will Kontaktmann Amris anklagen," Der Spiegel online, January 2, 2017, http://www.spiegel.de/politik/ausland/anis-amri-tunesienwill-kontaktmann-anklagen-a-1132958.html.

See protocols of the special meetings No. 101, January 5, 2017; 103, January 19, 2017; 105, February 2, 2017, https://www.landtag.nrw.de/portal/WWW/ dokumentenarchiv/Dokument/MMD16-1564.pdf; www.landtag.nrw.de/portal/ WWW/dokumentenarchiv/Dokument/MMD16-1582.pdf; www.landtag.nrw.de/ portal/WWW/dokumentenarchiv/Dokument/MMD16-1594.pdf.

20 "Kraft setzt Sonderermittler im Fall Amri ein," Zeit online, January 25, 2017, http://www.zeit.de/politik/deutschland/2017-01/nordrhein-westfalen-hannelorekraft-anis-amri-berlin-attantaeter-sonderermittlung. See also "Sonderermittler soll Fall Amri aufklären," Handelsblatt online, January 25, 2017, www.handelsblatt.com/ politik/deutschland/nach-berlin-anschlag-sonderermittler-soll-fall-amri-aufklaeren/ 19301674.html. Hinting at the establishment of an ad hoc parliamentary inquiry: “Politik Kompakt I," Welt online, February 8, 2017, www.welt.de/print/die_welt/ politik/article161895769/ Politik-Kompakt-I.html; and "Ausschuss in NRW soll Fall Amri untersuchen," Zeit online, February 7, 2017, http://www.zeit.de/politik/ deutschland/2017-02/anschlag-breitscheidplatz-anis-amri-landtag-duesseldorfuntersuchungsausschuss. Kretschmer submits controversial report: "Fall Amri: Grüne attackieren Krafts Gutachter," Express online, March 30, 2017, www.express.de/news/politik-und-wirtschaft/fall-amri-gruene-attackieren-kraftsgutachter-26284776. 
meetings of the Berlin-located GTAZ. NRW security staff participated in those meetings ${ }^{21}$ and stressed Amri's potential on February $17^{\text {th }}, 2016$. Contrary to this opinion, the representatives of the federal police, the BKA, assessed the danger as unlikely. ${ }^{22}$

As mentioned before, the Special Investigator also said that Anis Amri could not have been taken into custody after his asylum application was rejected.

\section{Ad hoc Inquiry Committee}

In light of the public outrage about the case, a demand to establish an ad hoc inquiry arose. ${ }^{23}$ The committee was established by NRW's House of Deputies on February $15^{\text {th }}, 2017 . .^{24}$ In spring 2017 , this inquiry developed as the first key arena to shed light on the plot. It quickly assessed the available documents and summoned home ministers, including the Federal Minister for Home Affairs Thomas de Maizière (Conservative Party). Ad hoc inquiry committees are subject to the principle of discontinuity. This means that they last as long as the legislative term. ${ }^{25}$ Accordingly, the NRW committee came to an end due to elections in NRW in May 2017. The NRW committee published a 175-page interim report in April 2017. Nevertheless, this report does not contain a final statement on the findings but only provides the current state of the inquiry. The newly elected NRW parliament set up a new inquiry committee which started work in June ${ }^{26}$ and has so far only held an initial meeting.

21 "Terrorfall Amri - Sonderermittler entlastet die Behörden in NRW," Der Tagesspiegel online, March 27, 2017, http://www.tagesspiegel.de/politik/terrorfall-amrisonderermittler-entlastet-die-behoerden-in-nrw/19577652.html.

22 “Berlin Attack: An Attack is Expected," Zeit online, April 5, 2017, www.zeit.de/politik/ deutschland/2017-04/berlin-attack-christmas-market-breitscheidplatz-anis-amri.

23 "Verfassungsschutz belastet Landeskriminalamt," rbb24, February 9, 2017, www.rbbonline.de/politik/beitrag/2017/02/Verfassungsschutz-Palenda-schiebt-Schuld-imFall-Amri-von-sich.html.

24 "NRW beschließt Untersuchungsausschuss zum Fall Amri," Der Tagesspiegel online, February 15, 2017, www.tagesspiegel.de/politik/berlin-attentaeter-nrw-beschliesstuntersuchungsausschuss-zum-fall-amri/19396466.html.

${ }^{25}$ On the function and rights of the Parliamentary Control of the Intelligence Services see Dietmar Peitsch, Christina Polzin, "Die parlamentarische Kontrolle der Nachrichtendienste," Neue Zeitschrift für Verwaltungsrecht 4 (2000): 387-93. Inquiries usually end by submitting a report with recommendations to the Speaker of Parliament.

26 "Terrorfall Amri: Ausschuss im neuen NRW-Landtag nahm Arbeit auf," Westdeutsche Zeitung online, June 27, 2017, http://www.wz.de/home/politik/inland/landtagswahlnrw/terrorfall-amri-ausschuss-im-neuen-nrw-landtag-nahm-arbeit-auf-1.2463395. 


\section{Federal Level}

The question remains if a federal inquiry committee would have been able to provide the full picture of the incident. ${ }^{27}$ The Breitscheidplatz attack proved that some security-related questions go beyond nation- and interstate borders. Moreover, the roles of the Federal Office for Migration and Refugees (Bundesamt für Migration und Flüchtlinge, BAMF) as Germany's central authority dealing with refugees as well as the federal authorities gathered in the GTAZ, such as the Federal Criminal Police Office (BKA), the Federal Intelligence Service (Bundesnachrichtendienst, BND) and the Federal Office for the Protection of the Constitution (Bundesamt für Verfassungsschutz, BfV) seem to deserve an examination. A pure Länder-focused approach could miss transnational components of the plot like Amri's criminal past in Italy and the track he chose escaping to Milan. Since the 16 states have a limited ability to deal with foreign affairs, the international entanglement suggests the involvement of Germany's federal level. ${ }^{28}$

Federal decision-makers quickly realized that some sort of ex post investigative attempts by the German Bundestag were due. In January 2017, the Parliamentary Control Panel (Parlamentarisches Kontrollgremium, PKGr) began to discuss the incident in the light of possible errors by the intelligence service. ${ }^{29}$ An ad hoc parliamentary inquiry committee of the German Bundestag has so far not been set up.

27 "Rufe nach Neuorganisation der Terrorabwehr," Handelsblatt online, February 2, 2017, http://www.handelsblatt.com/politik/deutschland/berliner-terroranschlag-rufenach-neuorganisation-der-terrorabwehr/19269704.html. See also "Fall Amri: Neue Antworten - neue Fragen," Berliner Morgenpost online, February 3, 2017, http://www.morgenpost.de/politik/article209485027/Fall-Amri-Neue-Antworten-neue-

Fragen.html. Berlin/Düsseldorf blame game: "NRW-Landesregierung muss sich kritische Fragen gefallen lassen," FAZ online, February 13, 2017, http://www.faz.net/ aktuell/politik/kritik-an-nrw-innenminister-jaeger-fall-anis-amri-14876497.html.

"Der Antiterrorkrampf," Der Spiegel online, January 22, 2017, www.spiegel.de/ spiegel/anis-amri-und-der-anschlag-von-berlin-ermittlungspannen-keine-aufklaerung-a1131008.html. See also “Polizei führte Anis Amri kurz vor der Tat als Terrorist," Der Tagesspiegel online, January 16, 2017, www.tagesspiegel.de/politik/attentat-aufbreitscheidplatz-polizei-fuehrte-anis-amri-kurz-vor-der-tat-als-terrorist/19259836.html; and "Italiens Behörden verschwiegen schwere Panne im Fall Amri," Welt online, January 22, 2017, www.welt.de/politik/deutschland/article161386891/ItaliensBehoerden-verschwiegen-schwere-Panne-im-Fall-Amri.html.

On the function and rights of the Parliamentary Control of the Intelligence Services see: Dietmar Peitsch, Christina Polzin, "Die parlamentarische Kontrolle der Nachrichtendienste," Neue Zeitschrift für Verwaltungsrecht 4 (2000): 387-93. 


\section{Internal Affairs Committee}

The Bundestag's committee on internal affairs discussed the issue in several non-public meetings, inter alia on January $18^{\text {th }}$ and February $13^{\text {th }}, 2017$. During the meeting in February, the Ministers of Home Affairs of Berlin and NRW as well as the heads of the BND, the BfV, the BKA and other authorities were questioned. The committee and the authority's representatives discussed different legislative proposals, such as the modification of the Asylum Act. ${ }^{30} \mathrm{~A}$ Member of the Internal Affairs Committee pointed out that the state level cannot solely be blamed for failures in the Amri case. He also stressed a responsibility of the federal level and kept lobbying for the establishment of a parliamentary inquiry. ${ }^{31}$

\section{Parliamentary Control Panel}

In a special meeting on January $16^{\text {th }}, 2017$ the PKGr sub-assigned the former Head of Germany's Mol Legal and General Affairs of Public Security Department, Arne Schlatmann, to investigate the plot. His work was accompanied by four PKGr members from different parties. ${ }^{32}$ The findings were submitted to the German Parliament in an open final report on May $31^{\text {st }}, 2017 .{ }^{33}$ Since the PKGr has no supervisory power over aspects that fall under the jurisdiction of the states, the report covers only action or inaction of federal entities like the $B K A$, the BfV, and the BND. According to the PKGr, those agencies had only had a supporting function in the Amri case. The main security actors were the competent authorities in the state of NRW and the City of Berlin, as well as the competent institutions gathered in the GTAZ. The PKGr concludes that those authorities should have recognized Amri's potential. Therefore, the PKGr wondered why no further actions against Amri were taken to prevent the attack. The Panel also criticized Amri's mobility within Germany causing different judgments by different authorities. The report highlighted the shortcomings of the immigration authorities in not taking further action to detain Amri after his application for asylum was rejected.

\section{Ad hoc Committee of Inquiry}

As stated above, an ad hoc parliamentary inquiry committee of the German Bundestag was not set up. The refusal to review the case on the federal level is surprising in light of the intense public debates usually sparked by inquiries, the

30 See press release of the German Bundestag, February 13, 2017, www.bundestag.de/ presse/pressemitteilungen/2017/pm-170209-pm-amri/492512.

31 Ibid.

32 The legal base for this procedure is $\S 1$ Absatz 1 in conjunction with $\S 5$ a PKGr statute (Kontrollgremiumgesetz).

33 "Unterrichtung durch das Parlamentarische Kontrollgremium," Bundestag Drs. 18/ 12585, May 31, 2017, http://dip21.bundestag.de/dip21/btd/18/125/1812585.pdf. 
past record of conducted inquiries and the far-reaching legal rights of the members of Parliament to assess files and to question officials including ministers and the Chancellor. The Bundestag would have had the time in January 2017 to launch an investigation since the federal elections were scheduled for September 2017. The deputies in Düsseldorf made the attempt and could at least review files and summon some major witnesses in a much shorter time between February and April 2017.

To understand the full potential of an ad hoc committee of inquiry as an adequate tool to review incidents like the Berlin attack, a short look into the legal framework and the political background of such investigations is helpful. Ad hoc committees are meant to find governmental misconduct or legal violations by gathering and evaluating evidence and to provide recommendations to prevent further fault. The implementation of ad hoc inquiry committee by a qualified minority of the parliament is the most intense constitutional tool of Germany's legislative bodies because they foster public debate about the case, the performance of the involved security agencies, and the entire applicable legislative set-up related to the plot. The selected members of a parliamentary committee of inquiry enjoy unrestricted access to classified material and benefit from the witnesses' duty to appear at the hearings. ${ }^{34}$

When looking at the ad hoc committees of inquiry since Germany's reunification, the ratio of security versus non-security topics investigated yields a higher ratio than expected. Six particular investigations into such areas as energy safety, political party financing, wide-spread diseases, and bad bank scandals took place since Germany's reunification in 1990. In the same period, twelve inquiries focused on alleged misconduct by security bodies. Amongst the best known inquiries were the investigations on the role of BND staff in Bagdad during the 2003 Iraq War, alleged German involvement in rendition cases, an air strike against hijacked fuel tanks near a German Army camp in Kunduz, Afghanistan, the failure of security authorities to stop serial murders by a Neo-Nazi trio, ${ }^{35}$ as well as the impact of the so-called Snowden Leaks and Berlin's eventual collaboration. ${ }^{36}$ In sum, security matters are investigated twice as often as non-security issues. This ratio suggests that the security agencies themselves constitute the biggest threat to Germany and its citizens. Following this legacy, the Amri case would have perfectly suited the Bundestag's appetite to investigate security sector misconduct. For some reason this did not

34 Sebastian von Münchow, "Security Agencies and Parliamentary Committees of Inquiry in Germany: Transparency vs. Confidentiality," Connections: The Quarterly Journal 12, no. 4 (2013): 51-74, https://doi.org/10.11610/Connections.12.4.03.

35 The NSU ("National Socialist Underground") was a right-wing terrorist group which managed to remain undetected for more than a decade. The final report of the Committee is available at http://dip21.bundestag.de/dip21/btd/18/129/1812950.pdf.

36 The final report of the Committee is available at http://dip21.bundestag.de/dip21/ btd/18/128/1812850.pdf. 
take place, leaving a bitter taste and suspicion that the very constellation of the Breitscheidplatz plot was perceived as politically inconvenient to establish a thorough ex post investigation.

\section{Achievements}

Returning to the plot, the record of the fora of inquiry on the state level is mixed. Certainly, the blame game between the security architectures in the City of Berlin, Düsseldorf, and from the federal level have not contributed to public trust in the functioning of German law enforcement or intelligence authorities. Consequently, Federal Minister for Home Affairs Thomas de Maizière said: "in cases like Amri we urgently need more commitment and unity among the authorities of the federal government and the states." This statement was widely criticized by the respective Ministers on the Länder-level. ${ }^{37}$ They feared that the genuine power to maintain public order and security on the Länderlevel was intended to be undermined to the advantage of the federal level. Hence, the challenge is to strike a balance between promoting cooperation and aligning police work while maintaining the federalist separation of power.

An example may illustrate the background of this state-federal level mistrust. The term "Gefährder" describes a person who is believed to have the potential to conduct a terrorist attack. The term exists in all respective state legislation. What differs is how state officials interpret the term "Gefährder." While the threshold could be low in some states, it may be high in others. A standard understanding does not exist. Consequently, the federal level started to call for a common approach to defining terms like "Gefährder." This very call made ministers on the state level fear an emerging federal power patronizing Länder-police work. This overlooks that the federalist system could in fact be strengthened. A common understanding between state and federal authorities does not mean that law enforcement agencies on the Länder-level lose their capabilities to operate in their territorial jurisdictions. The different levels are best reconciled when understanding the mutual benefit from enhanced communication, cooperation and applying common definitions. ${ }^{38}$

The case also kicked in some reforms to prevent similar attacks in the future. First, a law to improve the data exchange between the authorities of the states (Datenaustauschverbesserungsgesetz) came into force. This should help preventing possible attackers from using different identities to apply for asylum

37 "Um die Vorschläge von Innenminister de Maizière ist ein heftiger Streit entbrannt das sind die Fakten," The Huffington Post, April 1, 2017, www.huffingtonpost.de/ 2017/01/04/de-maiziere-konzept-siche_n_13947896.html.

38 "Reform der Sicherheitsbehörden - Wie wär's mit einem deutschen FBI?" Spiegel Online, August 22, 2017, http://www.spiegel.de/panorama/justiz/sicherheit-indeutschland-wie-waer-s-mit-einem-deutschen-fbi-a-1162781.html. 
in different states in Germany. ${ }^{39}$ Second, a system for a standardized risk analysis of certain persons was implemented. The work on the RADAR-iTE system ${ }^{40}$ was already finished in September 2016 and has been gradually implemented by summer 2017 . The aim is to provide a standardized risk analysis tool for the relevant entities on state and federal level. Third, the vehicular ramming attack boosted a bilateral understanding to return Tunisian nationals who have not been granted asylum in Germany. This system is currently being utilized on a bilateral level between Tunisia and Germany. ${ }^{41}$

Finally, a new legal framework empowers the BKA with more efficient tools to fight terrorists. The use of ankle restraints was introduced. The procedure to arrest potential attackers who are obliged to leave the country was eased. All these developments had already begun before the vehicle ramming attack. But the Breitscheidplatz plot caused the political dynamics to strengthen Germany's security structure. Other reforms are still on the agenda, e.g. improving data exchange between the 16 German states as well as between the Federal Republic and third countries or countering radicalization of individuals in Germany. $^{42}$

\section{Conclusion}

Beyond Germany's 2017 pre-national election's atmosphere, it remains speculative to find reasons why an inquiry on federal level was refused. Ad hoc inquiries have exposed wrongdoings and uncovered severe deficiencies in the past 27 years, although the final reports have rarely suggested that German officials violated national or international law. Usually these inquiries lead to stronger parliamentary control over the security sector. In addition, many intraagency restrictions were introduced. These restrictions received criticism for having immobilized the security sector's capabilities to a critical degree in the past decades. In parallel, a large scale-down of military, police and intelligence

39 The press release of the German government about the implementation and benefits of the statute is available at www.bundesregierung.de/Content/DE/Artikel/2015/ 12/2015-12-09-datenaustauschverbesserungsgesetz-fluechtlingsausweis.html.

40 The press release of the German federal police about the implementation of the RADAR-iTE system is available at https://www.bka.de/DE/Presse/Listenseite_ Pressemitteilungen/2017/Presse2017/170202_Radar.html.

41 "Rückführung von Flüchtlingen - Deutschland und Tunesien starten Pilotprojekt für Abschiebungen," focus online, March 1, 2017, http://www.focus.de/politik/ ausland/migration-auch-tunesien-kooperiert-bei-abschiebungen-aus-deutschland_ id_5326677.html.

42 These topics are ongoing subjects of the political debate in the different committees on internal affairs. Different legislative and resolution proposals are currently discussed, such as the proposal to implement a nationwide prevention strategy against radicalization as proposed by the Party Bündnis 90/ die Grünen: http://dip21.bundestag.de/dip21/btd/18/104/1810477.pdf. 
staff put further pressure on the capacity of the security sector. Hence, a parliamentary investigation of the Amri case could have revealed the following: Legislative and staff constraints immobilized the German security architecture in a way that it was unable to tackle a radicalized Tunisian.

In sum, the work of the Special Investigators and the parliamentary inquiries have exposed many disadvantages of Germany's security architecture. While some needed reforms were introduced, Germany did not develop a blind ambition to introduce instruments that unnecessarily restrict civil rights and liberties. Most importantly, the attack did cause a public debate about readjusting counter-terrorism shortcomings with a focus on cooperation between different Länder and federal authorities. This might empower the affected agencies to function in the light of a statement made by Thomas de Maizière right after the Breitscheidplatz attack: "The state is not the adversary of a free society but its instrument [...]. The democratic state doesn't threaten freedom, it protects it." $^{\prime 43}$

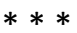

The views expressed in this paper are solely those of the authors and do not reflect those of any institution.

\section{About the authors}

Dr. Sebastian von Münchow is a lecturer at the George C. Marshall European Center for Security Studies. He studied law and political science in Berlin, Lausanne and Vienna. After receiving the Masters of Law, he became a member of the Berlin bar. He earned his doctorate in international relations from the University of Vienna. Dr. von Münchow then worked for the field missions of the Organization for Security and Co-operation in Europe in Bosnia and Herzegovina, as well as in Kosovo. He has also served in the Police Assistance Mission of the European Community in Tirana. In Brussels, he joined the Office of the Special Coordinator of the Stability Pact for South Eastern Europe. After returning to Berlin, Dr. von Münchow worked for the German Government.

E-mail: sebastianvonm@marshallcenter.org.

Lena Hantschke studied law at Humboldt University Berlin. She received the Masters of Law in 2015 and worked for the research service of the German Parliament, Bundestag. Ms. Hantschke then became a legal clerk at the Berlin Supreme Court, which seconded her to the Marshall Center in summer 2017. Lena Hantschke recently became a member of the Berlin bar. Her Ph.D. will focus on current challenges to the German security architecture.

E-mail: LL.Hantschke@hotmail.com.

43 As quoted in Matthew Karnitschnig, "Terror sparks call to centralize German police powers," Politico, January $3^{\text {rd }}, 2017$, http://www.politico.eu/article/terror-sparkscall-to-centralize-german-police-powers-berlin-isil-security. 